\title{
Regir el concejo, servir al señor: los regidores del concejo de Piedrahíta en el siglo XV
}

\author{
Corina Luchía ${ }^{1}$
}

Recibido: 11 de septiembre de 2018 / Aceptado: 05 de noviembre de 2018

Resumen. En el presente trabajo nos proponemos comprender la dinámica sociopolítica de un concejo de jurisdicción señorial a partir del análisis de la actividad de sus oficiales principales. El estudio de la gestión municipal a través de los documentos del concejo de Piedrahíta en el siglo XV permite reconocer las cualidades sociológicas de los miembros de la elite dirigente, así como los atributos de los oficios locales. De este modo, la investigación considerará las relaciones de las autoridades urbanas con el poder señorial de la casa de Alba, tomando como escenario de análisis las actuaciones de sus regidores.

Palabras clave: Regidores; Elite dirigente; Señorío; Piedrahíta; Siglo XV.

\section{[en] To Govern the Council, to Serve the Lord: the Regidores of the Council of Piedrahíta in the Fifteenth Century}

\begin{abstract}
In this work we intend to understand the sociopolitical dynamics in a manorial council based on the analysis of the activity of the main officials. The study of municipal management through the documents of the council of Piedrahíta of the fifteenth century allows recognizing the sociological qualities of the ruling elite and the characteristics of local offices. In this way, the research will take into account the relationships of the urban authorities with the manorial power of the House of Alba, from the performances of the leading figures.
\end{abstract}

Keywords: Regidores; Ruling elite; Manorial; Piedrahíta; fifteenth century.

Sumario. 1. Introducción. 2. Un concejo bajo señorío. 3. Integración del concejo y trayectoria de sus regidores. 4. Entre el señor y la comunidad. 5. Reflexiones finales. 6. Bibliografía.

Cómo citar: Luchía, C. (2019), Regir el concejo, servir al señor: los regidores del concejo de Piedrahíta en el siglo XV, en En la España Medieval, 42, 9-33.

\section{Introducción}

Las sociedades concejiles castellanas constituyen un objeto de permanente interés para los medievalistas; especialmente, las comunidades de villa y tierra y su papel en el desarrollo de la centralización política han motivado una abundante producción historiográ-

\footnotetext{
1 Instituto de Historia de España "Claudio Sánchez Albornoz”, Universidad de Buenos Aires-CONICET. corinaluchia@filo.uba.ar ORCID: 0000-0002-0147-4844.
} 
fica $^{2}$. Los diferentes trabajos en torno de los gobiernos municipales y sus contradictorios vínculos con los poderes superiores a finales de la Edad Media presentan un escenario histórico tan rico como problemático que nos aproxima a la actividad de las instancias locales de toma de decisiones, así como a los atributos de sus grupos dirigentes ${ }^{3}$.

Para estos complejos siglos, las interpretaciones respecto del impacto sobre las estructuras comunitarias de los procesos de señorialización han sido disímiles. Si entre los institucionalistas se considera que el nuevo encuadramiento señorial modifica radicalmente las organizaciones concejiles, las contribuciones de la historia social introducen matices que permiten advertir la fortaleza de las comunidades, en el contexto del despliegue "hacia arriba" del poder regio ${ }^{4}$. Numerosos estudios de caso describen las consecuencias del trasvase jurisdiccional sobre las condiciones de vida de la población. No obstante, la preocupación por el fenómeno señorial en su conjunto desplazó el análisis de la dinámica que asumen los órganos políticos locales sometidos a señores privados ${ }^{5}$. Por fuera de los aspectos estrictamente institucionales, referidos a las formas de nombramiento de los cargos concejiles y sus atribuciones, las prácticas sociales y políticas efectivas, y las relaciones de poder en las villas señorializadas siguen siendo cuestiones problemáticas ${ }^{6}$.

En las páginas que siguen, nos proponemos analizar el funcionamiento del concejo de Piedrahíta en el siglo XV, perteneciente al señorío de Valdecorneja, otorgado al poderoso linaje nobiliario de los Álvarez de Toledo ${ }^{7}$. La vasta documentación municipal y las disposiciones señoriales constituyen fuentes indispensables para el estudio de las actuaciones de los oficiales y de sus modalidades de gestión.

¿Qué cualidades exhiben los oficios del concejo? ¿Qué características asume la relación entre los regidores y el poder señorial? ¿Cuál es el margen de autonomía que conservan las entidades comunitarias? ¿Qué atributos adquieren las oligarquías locales en este ámbito jurisdiccional? Estos son algunos de los interrogantes a partir de los cuales será posible un acercamiento al gobierno concejil en este marco particular, teniendo como objetivo prioritario reconocer las prácticas que expresan balances de fuerzas y definen campos de acción social.

\section{Un concejo bajo señorío}

En el contexto de la compleja relación de competencia y colaboración entre los linajes nobiliarios y la monarquía castellana ${ }^{8}$, los soberanos efectúan distintas conce-

2 Entre otros, Monsalvo Antón, El sistema político concejil; Goicolea Julián, "Sociedad y poder concejil”; Clemente Ramos, "Estructura concejil" y las Actas del II Congreso de Estudios Medievales: Concejos y ciudades, especialmente Estepa Díez, "El concejo y el señorío jurisdiccional" y Bonachía, "El concejo como señorío". Sobre la evolución de las comunidades de villa y tierra, Martínez Díez, Las comunidades de villa y tierra.

3 Bonachía Hernando y Martín Cea, "Oligarquías y poderes concejiles"; Jara Fuente, "Estructuras formales de poder"; Ruiz de la Peña, "El régimen municipal de Plasencia"; Moreno Núñez, "El regimiento de Toro"; Lozano Castellanos, "Controlando el regimiento".

4 Las concesiones señoriales, si bien debilitan el realengo, también refuerzan "al rey como vértice político", dentro de "esa elevación hacia arriba de la monarquía hasta perder buena parte de su vieja condición domanial, o sea, el «lastre» de su viejo señorío directo", Monsalvo Antón, “Centralización monárquica castellana”, pp. 30-31.

5 Entre los escasos trabajos que abordan este problema, destacamos Muñoz Gómez, "El concejo de Peñafiel”.

6 El poder como conjunto de instancias y prácticas que inciden en la toma de decisiones, más allá del espacio formal del ayuntamiento, en Jara Fuente, "Posiciones de clase", p. 513.

7 Acerca de la concesión de este señorío, Moxó, "Los señoríos", pp. 400-404.

8 El papel del faccionalismo nobiliario como factor de presión en la conformación de los estados señoriales en Monsalvo Antón, "Relaciones entre nobleza y monarquía", especialmente p. 156. 
siones señoriales a costa del amplio término del concejo de Ávila9. Algunas de ellas, las más tempranas ${ }^{10}$, compensan el servicio prestado por los miembros de las oligarquías urbanas que se incorporan a las filas de la baja nobleza local ${ }^{11}$; otras, como las que benefician a la casa de Alba, resultan de la política frente a los grandes del reino que adoptan los soberanos a fines de la Edad Media ${ }^{12}$.

Los territorios que se incorporan a la unidad jurisdiccional de Valdecorneja ya habían sido detraídos del concejo abulense a mediados del siglo XIII por Alfonso X, en favor de su hermano el infante don Felipe ${ }^{13}$. Todo parece indicar que a comienzos del siglo XIV estas villas y lugares retornaron al realengo ${ }^{14}$, hasta su posterior entrega a García Álvarez de Toledo en 1369; momento en el que se constituye el primer señorío nobiliario del alfoz de Ávila ${ }^{15}$. No obstante, en las postrimerías del reinado de Juan II, las profundas disputas entre la casa de Alba y la Corona ${ }^{16}$, especialmente a partir de la ofensiva del príncipe de Asturias contra Fernán Álvarez de Toledo, provocan el encarcelamiento del conde y el secuestro de sus villas ${ }^{17}$.

Durante los seis años que permanece Fernán en prisión, el ejercicio de la jurisdicción queda en manos del futuro rey Enrique IV, a través del nombramiento de un justicia mayor ${ }^{18}$. La actuación de este oficial en el marco de la "confiscación del señorío"19, nos acerca al papel que desempeña en este proceso la minoría privilegiada abulense. De allí que la primera designación corresponda a Gómez de Ávila, uno de los caballeros más prominentes del linaje que ostenta el señorío de San Román, de notable protagonismo tanto en el concejo como en la corte regia ${ }^{20}$.

Sin pretender abordar en detalle la evolución de este núcleo señorial, cuestión sobre la que existen notables trabajos, ni tampoco examinar de manera acabada las relaciones entre Ávila y los territorios segregados que se incorporan al señorío de Valdecorneja, algunos elementos nos permiten matizar la idea de los efectos de la señorialización en términos de una separación absoluta de la vida de las comunidades de ambos espacios ${ }^{21}$. Distintas circunstancias plantean vasos comunicantes entre la

9 Moreno Núñez, Ávila y su tierra, pp. 107 y ss.

10 Sobre estos señoríos tempranos, Ibidem, pp. 98 y ss.

11 El caso de los Dávila, poderoso linaje de caballeros abulenses, ha sido estudiado, entre otros, por Moreno Núñez, "Los Dávila".

12 Sobre la concesión del señorío de Valdecorneja, al que pertenece Piedrahíta, Luis López, La comunidad de villa y tierra de Piedrahita, pp. 153-155.

13 Sobre la segregación del realengo y la etapa de los infantazgos, véase Idem.

14 La exigencia de Alonso XI al obispo Sancho Blázquez de Ávila: “que Buenfoyo e Los Forcajos e Çapardiel, que son en Valdecorneja, en término de Ávila (...) manda al obispo que las tiene que ge las dexe desenbargadamente” (1330, mayo 12), Luis López y Ser Quijano, Documentación Medieval del Asocio, t. I, doc. 30, p. 81, señala la condición realenga de estos espacios.

15 Señorío integrado inicialmente por las villas de Piedrahíta, El Barco de Ávila, El Mirón, La Horcajada, Moreno Núñez, Ávila y su tierra, p. 109.

16 Los avatares de este enfrentamiento en Calderón Ortega, El ducado de Alba, pp. 55-56.

17 Las motivaciones políticas que conducen al encarcelamiento y al secuestro de las villas mediante cédula de Juan II del 18 de mayo de 1448 y la "inquina del príncipe don Enrique", que cobra la dimensión de una "catástrofe que se cernía sobre el estado señorial”, en Calderón Ortega, "Los riesgos de la política”, pp. 43 y 45.

18 Luis López, La comunidad de villa y tierra de Piedrahita, p. 275.

19 Calderón Ortega, "Los riesgos de la política", p. 45.

20 Moreno Núñez, "Los Dávila”, pp. 165 y 168. Ya entronizado Enrique IV, Gómez de Ávila, sexto señor de San Román y Villanueva se desempeña como su guarda mayor, Moreno Núñez, "Los señoríos de Navamorcuende", p. 105.

21 Un asunto de índole privada, pero que involucra a figuras con posiciones institucionales relevantes en ambos espacios, es el conflicto entre el regidor abulense Nuño Rengifo y el alcaide y regidor de Piedrahíta Francisco de Salazar, por el casamiento forzoso de la hermana de Nuño: “diz que la dicha doña Juana está en la dicha villa 
ciudad de realengo y el concejo señorial. Así entendemos la presencia del corregidor en tierra de Piedrahíta, cuyos gastos deben ser sufragados por la villa: "echaron de costa que fizo el corregidor de Ávila e otros con él, quando vino a fazer alarde de la dicha villa e su tierra, quatroçientos e tres maravedís e un cornado"22; del mismo modo que debe costearse el mantenimiento "quando vino aquí a Piedrafita Gonçalo Rrodríguez, alcalde de Ávila, con cartas del rrey en rrazón de las carretas de buéys que avían de yr maheridos"23. En el mismo sentido, la gestión de las obligaciones regias y de las correspondientes al obispado de Ávila motiva la presencia regular de oficiales abulenses en la villa ${ }^{24}$, que traban relación con las familias principales y los personajes destacados del común ${ }^{25}$.

La presión fiscal se intensifica durante el prolongado enfrentamiento entre los hijos del prisionero conde de Alba y el príncipe don Enrique. La inestabilidad política y el contexto bélico provocan un incremento de las exacciones con el consiguiente esfuerzo para las poblaciones que integran el señorío ${ }^{26}$. De este modo, las consecuencias del cambio jurisdiccional son indisociables de las circunstancias en que la misma se lleva a cabo.

Algunas visiones destacan el carácter disruptivo de la señorialización sobre "las bases jurídicas y territoriales del concejo de realengo"27; por el contrario, Monsalvo Antón, indudable autoridad en el tema, ha considerado que en el caso de los concejos de villa y tierra no se produce la anulación de la personalidad jurídica de estas entidades $^{28}$, pese a las modificaciones que supone el encuadramiento bajo un titular privado.

En el plano de las propias organizaciones comunitarias, la privación "de los ofiçios que fasta aquí tenian los alcaldes e alguazil fasta que él ponga otros, a aqué-

de Piedrahíta en poder del dicho Françisco de Salazar e quél diz que en ella tiene grand fuerça e parentela de manera que puesto que requiriese a los juezes seglares de la dicha villa diz que dellos non se alcanzaría aquella ayuda" (1492, agosto 16), Martín Rodríguez, Documentación Medieval Abulense, vol. VII, doc. 40, p. 110.

22 Luis López, Documentación medieval de Piedrahita (en adelante Piedrahíta), vol. I, doc. 56, p. 199 (1438, junio 22).

23 Su presencia "fizo de costa dos maravedís de huevos, e seys maravedís de una pescada, e quatro maravedís e quatro cornados de vino, e dos maravedís de pan, e siete maravedís de media fanega de çevada", Ser Quijano, Las finanzas de un concejo, vol. II, p. 77.

24 En las cuentas del concejo del año 1426 consta que se dio al regidor de Ávila, Rodrigo Ordóñez, "rrecabdador del pedido e moneda (...) del obispado de Ávila quando vino a presentarse por rrecabdador con las cartas del rrey e a rrecabdar los maravedís que montó a Piedrafita e su tierra, que gastó el e sus omnes e bestias noventa e tres maravedís", Calleja Puerta, Las finanzas de un concejo, vol. I, p. 209.

25 En 1416, Clara Blázquez, esposa del regidor Fernán Martínez, recibe 500 mrs. "porque posó en su casa Gonçalo Gonçález de Toro, rrecabdador del rrey”, y en 1426 "dieron a Andrés Sánchez, platero, çinquanta e çinco maravedís porque estuvieron en su casa el rrecabdador del pedido del rrey e de las monedas e sus omnes", Calleja Puerta, Las finanzas de un concejo, vol. I, pp. 96 y 200.

26 Calderón Ortega señala el "socorro extraordinario" exigido a las villas de Valdecorneja en 1451 para el sostenimiento de los hijos del conde y el pago de sus gentes de armas durante la resistencia militar, "Los riesgos de la política", p. 49.

27 López-Guadalupe Pallarés revisa críticamente estas interpretaciones en "Proceso de señorialización", p. 434. Por contraste, López Pita sostiene que la mayoría de los nuevos señoríos bajomedievales no respetan el estatuto precedente de los campesinos, "Señoríos nobiliarios”, p. 259 y Mínguez Fernández considera que la absorción señorial supuso una "drástica reducción de las autonomías municipales" en materia judicial, administrativa y económica, "La resistencia antiseñorial", p. 224.

28 Monsalvo Antón, "Las dos escalas de la señorialización”, p. 323. El interés señorial por controlar el nombramiento de los oficiales y dificultar la autonomía financiera concejil en García Oliva, "Señores contra campesinos", pp. 321-322. 
1los que él entendiere que cunple a serviçio del dicho señor rey e suyo"229, constituye una alteración significativa. El evidente rechazo inicial que este cambio genera ${ }^{30}$ es aplacado por una combinación de coerción y amenaza sobre la comunidad concejili ${ }^{31}$. Sin embargo, las condiciones concretas de la señorialización continúan siendo motivo de reclamos y de negociación por parte de los sectores encumbrados de la villa ${ }^{32}$. El nuevo marco implica para las familias que ya ocupaban posiciones de preeminencia en el concejo tanto una amenaza como una oportunidad.

Sin desconocer las restricciones que el traspaso jurisdiccional importa para la organización política local ${ }^{33}$, resulta indispensable estudiar la dinámica que asume el ayuntamiento sujeto a titularidad privada, avanzando en la posibilidad de pensarlo como un espacio a medio camino entre la mera agencia señorial y la afirmación de poderes oligárquicos relativamente independientes. Llegados a este punto, la comparación con la situación de los concejos que permanecen en el realengo es insoslayable ${ }^{34}$.

El cierre que experimentan las comunidades de villa y tierra de toda el área de la Extremadura ${ }^{35}$, mediante el cual la asamblea abierta de vecinos se transforma en un cuerpo exclusivo de oficiales, se verifica también en Piedrahíta, con la aparición de personajes encargados "de veer fazyenda del dicho conçeio" 36 . Los individuos que asumen las regidurías comparten sus tareas con una serie de agentes de diversa procedencia y función ${ }^{37}$. La minoría dirigente es seleccionada dentro del círculo de los caballeros ${ }^{38}$, estamento que defiende su prevalencia en la ocupación de los cargos principales, en detrimento de las capas inferiores de los privilegiados y del común ${ }^{39}$. Hasta aquí la condición señorial de la villa pareciera no incidir diferencialmente en los procesos de oligarquización comunes a todo el sistema concejil; sin embargo, algunas circunstancias permiten reconocer las singularidades de este desarrollo.

29 Se trata del pleito homenaje de los representantes de la Horcajada, Calderón Ortega, Documentación medieval abulense en el archivo de la Casa de Alba, doc. 4, p. 23; el mismo antecede al que realizaran en 1464 los vecinos de Piedrahíta, Luis López, Colección Documental del Archivo Municipal de Piedrahíta, doc. 17, pp. 51-54. La remoción de los cargos municipales como consecuencia de la toma de posesión señorial de la villa de Cáceres en Mínguez Fernández, "La resistencia antiseñorial", p. 224.

30 Calderón Ortega, Documentación medieval abulense, doc. 4.

31 Como consecuencia de esta política, las villas "lo desearan o no acabaron normalmente sucumbiendo a la señorialización", Monsalvo Antón, "Arraigo territorial”, p. 117.

32 La resistencia antiseñorial de los grupos dirigentes concejiles en Mínguez Fernández, "La resistencia antiseñorial", pp. 225-226.

33 Santos Canalejo señala: "El gobierno de Piedrahíta y su Tierra fue dirigido por el concejo de la villa, que estaba en manos de una oligarquía, y por el señor, que tenía la última palabra, mediante acuerdo tácito. De esta manera, el señor respetó a la oligarquía local, pero esta se supeditó a su voluntad para no perder la dirección del concejo", "Piedrahíta", p. 1156.

34 La praxis económica y administrativa diferenciada en el ámbito de realengo y de señorío es enfatizada por Bernardo Ares, "El régimen municipal", p. 32.

35 Dentro de la vasta producción sobre la instauración del regimiento castellano destacamos Monsalvo Antón, "La sociedad política en los concejos castellanos"; Val Valdivieso, "Oligarquía versus común”; y Jara Fuente, "Sobre el concejo cerrado".

36 Piedrahita, vol. I, doc. 3, p. 85 (1372, junio 18).

37 Miguel Sánchez es uno de los encargados "de veer fazyenda del dicho conçeio" en 1372, que aparece formalmente mencionado como regidor en 1401, Ibidem, doc. 5, p. 90 (1401, noviembre 03).

38 Desde el siglo XIV los grupos privilegiados están integrados por las principales familias de caballeros llegadas con la repoblación y por los agentes señoriales, Santos, Santos Canalejo, "Piedrahíta", p. 1146.

39 El rechazo de los caballeros a la designación señorial de un escudero para encargarse de las obras de la muralla y la posterior corrección de la medida son indicativos de este control exclusivista de las tareas de gestión comunitaria, véase Santos Canalejo, "Piedrahíta", p. 1158. 
En el realengo, la responsabilidad de ejecutar la soberanía monárquica transferida y el intervencionismo regio plasmado en el envío de los jueces corregidores no modifica las cualidades de los grupos dirigentes ni tampoco altera de manera radical la capacidad decisional y la fortaleza de estas elites ${ }^{40}$. En el caso de Piedrahíta, el diseño del concejo cerrado se encuentra "mediatizado por la presencia señorial" La irrupción en la vida local de la figura del alcalde mayor ${ }^{42}$, oficial que encabeza las reuniones del ayuntamiento y entiende en la administración de "las cavsas e negoçios çeviles e criminales" de los vasallos del conde ${ }^{43}$, expresa un nuevo cuadro de situación ${ }^{44}$.

Las tensiones que se generan en torno de este oficio manifiestan la complejidad del vínculo entre el concejo y el titular jurisdiccional ${ }^{45}$, no susceptible de interpretarse en términos de pasivo reconocimiento del vasallaje. Veamos el siguiente incidente. Alfonso de Herrera ${ }^{46}$, quien ocupa este cargo al menos desde $1462^{47}$, es requerido por el señor para cumplir otras funciones, motivo por el cual es reemplazado por el bachiller Juan Rodríguez de Cueto ${ }^{48}$. Los oficiales concejiles aprovechan esta circunstancia para cuestionar la apropiación por el delegado señorial de las competencias de los alcaldes ordinarios ${ }^{49}$. Frente a este malestar, el conde Fernando Álvarez de Toledo se ve obligado a ceder -"mi intençión nunca fue de vos agraviar"-, limitando las atribuciones de su oficial a las materias apelables ${ }^{50}$. Si las facultades de los alcaldes locales son defendidas celosamente por el concejo, su desempeño es censurado por el señor: "que a la verdad yo estoy enojado de los alcalldes pasados que tan relaxadamente se han avido en cunplir mis mandamientos" ${ }^{\text {"51. }}$.

La provisión y confirmación señorial de los oficios que completan la administración local son acompañadas de un acto de indudable significación simbólica: el regalo que el concejo entrega al conde de 42 pares de perdices, en manifiesta acep-

40 En el concejo de Ávila la monarquía formula los principios básicos que deberían seguir los oficiales locales para gestionar el "realengo transferido", estableciendo que "fagan e administren, conmo deven, las cosas del dicho conçejo (...) e regir e administrar, buena e fielmente, syn parçialidad alguna" (1480, noviembre 04), Luis López, Documentación Medieval Abulense, vol. II, doc. 82, p. 197.

41 Muñoz Gómez también enfatiza la intervención de los señores jurisdiccionales en la instauración de los regimientos, "El concejo de Peñafiel", pp. 73 y 78.

42 El papel de este oficial como delegado personal y representante supremo del señor en el concejo expresa una modalidad generalizada de gestión en las áreas señorializadas de Castilla, Ibidem, p. 81; también Calderón Ortega, "Los corregidores del duque de Alba". Las atribuciones de los alcaldes en Luis López, La comunidad de villa y Tierra de Piedrahita, p. 243 y ss.

43 Luis López, Piedrahíta, vol. III, doc. 76, p. 112 (1464, enero 04).

44 La presencia del alcalde mayor Juan Martínez de Tamayo es retratada en las actas de las reuniones concejiles desde 1435 (Piedrahita, vol. I, docs. 37, 40, 42) y se prolonga por lo menos hasta 1457, Ser Quijano, Piedrahita, vol. II, doc. 113, p. 242 (1457, marzo 02).

45 Acerca de las resistencias locales que genera la irrupción de este oficio, Muñoz Gómez, “Administración señorial", p. 174.

46 Herrera forma parte del entorno señorial desde mucho antes de obtener este puesto, habiendo asumido importantes responsabilidades en los años turbulentos de la prisión del conde; en 1451 debe reemplazar al primogénito García de Toledo como adelantado de Cazorla para que este organice la resistencia contra el príncipe don Enrique, Calderón Ortega, "Los riesgos de la política", p. 46.

47 Piedrahita, vol. III, doc. 18, p. 52 (1462, febrero 16).

48 Ibidem, doc. 76, p. 112 (1464, enero 04).

49 El señor señala: “dezydes que en mi carta se contenía quel bachiller Juan Rrodríguez, mi alcallde mayor, oyese de la primera cavsa, esto que lo avés por agravio, e que a los alcalldes ordinarios non conveníe de oýr, mi intençión nunca fue de vos agraviar" (1464, enero 14), Ibidem, doc. 79, p. 117.

$50 \quad$ Ibidem, doc. 79, p. 117 (1464, enero 14).

51 Ibidem, doc. 79, p. 117 (1464, enero 14). 
tación del vasallaje ${ }^{52}$. Ahora bien, ¿de todo esto se desprende la completa anulación de las fuerzas concejiles por parte del poder señorial del que serían estas sus simples agentes? Todo el episodio pone en evidencia la dialéctica entre el encuadramiento jurisdiccional y los márgenes reales de autonomía comunitaria, en una villa como Piedrahíta.

\section{Integración del concejo y trayectoria de sus regidores}

La selección de los oficiales, si bien supeditada a la voluntad del señor ${ }^{53}$, involucra activamente a la oligarquía local que incide en las designaciones $y$, fundamentalmente, conserva el control sobre el ejercicio efectivo de los cargos ${ }^{54}$. La provisión de regidurías nos permite reconocer los mecanismos de acceso a los puestos y los intereses detrás de ellos, dentro de una lógica transaccional que depende de la relación de fuerzas ${ }^{55}$. El origen -señorial o local-de los nombramientos constituye un criterio de diferenciación básica entre las dos fuentes de toma de decisiones que operan en el ámbito concejil ${ }^{56}$.

Si bien desde 1372 habitualmente es el titular jurisdiccional quien concede los oficios para cubrir la vacancia producida por el fallecimiento de su anterior ocupan$t^{57}$, las elites concejiles conservan un margen de actuación para nada desdeñable. En todos los casos, la exigencia del juramento de servicio al señor actualiza el lazo de vasallaje al que todo el colectivo se encuentra sujeto. Así se advierte en la requisitoria del conde de 1464:

al tienpo que vos confirmé vuestros ofiçios de rregimiento non fezystes el juramento que en tal caso hérades obligados de guardar mi serviçio e conplir mis cartas e mandamientos (...) mando que fagades el dicho juramento, ayuntados en vuestros conçejos (...) satisfagas a lo que soys obligados por razón de los dichos ofiçios $^{58}$.

La conformación del cuerpo colegiado de gobierno no es tampoco un mero procedimiento administrativo, sino que sirve de recordatorio de la subordinación señorial de la comunidad toda, pero especialmente de sus elites.

52 Idem. Estos presentes señoriales asumen un carácter habitual, como los "doze carneros e doze cántaras de vino blanco trasañejo e quatro açacanes e lías e enbueltas" que se entregan en 1437 para la Pascua o bien para Navidad, Ser Quijano, Las finanzas de un concejo, vol. II, pp. 73 y 83. El significado de estas rentas como reconocimiento simbólico del señorío en Reglero de la Fuente, "Imágenes, espacios, gestos y palabras", p. 100.

53 Monsalvo Antón diferencia el nombramiento, siempre señorial de los oficios, de la designación, que implica el "proceso real de toma de decisiones en el reclutamiento del personal político", "El reclutamiento", p. 174 (destacado en el original).

54 Santos Canalejo, "Piedrahíta", p. 1156.

55 Jara Fuente, Concejos, poder, elites, p. 102, esp. nota 37.

56 Monsalvo Antón, "El reclutamiento", p. 173, esp. nota 1.

57 A "Ximón de Plasençia, vecino de la mi villa de Piedrafita, fago vos merçed del ofiçio de rregimiento de la dicha mi villa que vacó (...) por fin e muerte de Ferrand González de Montenegro (...) para en toda vuestra vida" (1465, diciembre 18), Piedrahíta, vol. III, doc. 133, p. 189; "a vos, Alonso de Armenteros, vezino de mi villa de Piedrafita, fago vos merçed del ofiçio de rregimiento de la dicha mi villa que vaca por fyn e muerte de Sancho Gonçález (...) para en toda vuestra vida" (1467-11-15), Ser Quijano, Piedrahita, vol. IV, doc. 23, pp. 56-57.

58 Piedrahita, vol. III, doc. 105, p. 157 (1464, diciembre 22). 
Por otra parte, el fenómeno difundido en Castilla de los "regimientos acrecentados" adquiere también en Piedrahíta rasgos particulares. La ampliación del número de los oficiales asalariados no pareciera ser expresión del incremento del poder de la elite villana; por el contrario, es la propia voluntad señorial la que provee de estos nuevos puestos, aún contrariando sus propias disposiciones.

En 1447, don Fernando Álvarez de Toledo afirma: "yo tengo ordenado que en la dicha villa non aya sino quatro regidores salariados e yo fize merçed nuevamente de otro rregimiento de la dicha villa con salario, yendo contra la ordenanza por mí fecha en la dicha razón" 59 ; motivo por el cual ordena a su recaudador, Pedro de Guerra, que entregue al concejo "quatroçientos maravedíes para enmienda del salario de que yo proveý con el dicho rregimiento, fasta quel dicho rregimiento se consuma en uno de los dichos quatro rregimientos salariados" ${ }^{\prime \prime}$. Si en el realengo los soberanos tienden a combatir el aumento de los oficiales concejiles ${ }^{61}$, en el caso estudiado pareciera ser incentivado por el titular jurisdiccional ${ }^{62}$, que encuentra en esta estrategia un modo de consolidar sus apoyos locales.

Esta política, emanada desde el poder superior y contestada por algunos sectores de la oligarquía concejil desata un proceso de negociación en el que ambas partes deben ceder algo. En 1488, en los capítulos otorgados a petición de la villa de Piedrahíta, el duque de Alba "a lo que dezís que de costunbre antigua tenéys de aver seys regidores $(. .$.$) me suplicáys que no mande acreçentar el dicho numero e que mande$ que los dichos seys regidores rregidan los dichos ofiçios por sus vidas" ${ }^{\prime 3}$, responde "que se consuman los regimientos acresçentados, quando acaeciere vacar, fasta que queden en el número antiguo" ${ }^{64}$. No obstante, don Fadrique Álvarez de Toledo se reserva la potestad de "mandar proveer de algund rregimiento (...) e los que no se ovieren de consumir", aunque contemplando "que la merçed e provisión dél se faga a persona ábile e perteneciente para ello" ${ }^{65}$.

En otras circunstancias, las fórmulas de traspasos y renuncias, tan habituales en todo el reino, servirán para que los regidores transmitan los puestos a sus allegados. Este es el caso de Alonso Álvarez de Vergas, quien cede la regiduría a su hijo, García de Vergas, con la correspondiente provisión del señor ${ }^{66}$. De este modo, la cada vez

59 Piedrahita, vol. I, doc. 135, p. 305 (1447, septiembre 07).

60 Idem. Como señala de la Calle Sánchez, el otorgamiento de regidurías por orden y a cuenta del patrimonio señorial señala la relevancia de los servicios prestados al conde por los caballeros beneficiados, Estudio jurídicoeconómico, p. 329.

${ }_{61}$ En las Cortes de Palenzuela de 1435 se prohíben los oficios acrecentados, Cortes, t. III, Pet. 26, pp. 67-68. Dentro del intento de saneamiento administrativo del reino, las Cortes de Toledo de 1480 recogen esta orientación a través de la política de consumición de oficios: "los dichos officios (...) que fueron acrecentados (...) quando vacaren por muerte o privación (...) sean luego consumidos (...) sin otra provisión (...) e questos tales officios no puedan ser renunciados", Cortes, t. IV, Cortes de Toledo, ley 85, pp. 164-165.

62 El rechazo de la oligarquía local a la intrusión de nuevos regidores se expresa en las peticiones de 1464: "que vuestra señoría non porná ningund rregidor de nuevo demás de los que agora están, fasta que alguno fallezca" (1464, mayo 16), Piedrahita, vol. III, doc. 83, p. 126.

63 Luis López, Piedrahita, vol. V, doc. 16, p. 65 (1488, julio 15).

64 Ibidem, p. 66.

65 Idem.

66 "Fago saber a vos (...) que Alonso Álvarez de Vergas, rregidor de la dicha villa, fizo traspasamiento del ofiçio del dicho rregimiento a Garçía de Vergas, su fijo, e pidiome por merçed que le yo proveyese del dicho ofiçio de rregimiento al dicho Garçía" (1453, mayo 02), Piedrahíta, vol. II, doc. 59, p. 131. Diez días después, el flamante regidor se presenta en el concejo para ser recibido y prestar juramento (1453, mayo 12), Ibidem, doc. 60, p. 132. 
más firme disposición a perpetuidad de los oficios tiende a convertirlos en beneficios patrimonializados ${ }^{67}$, de acuerdo a la potencia de las familias que los ostentan ${ }^{68}$.

A lo largo del siglo XV se afianza el control de los regimientos por los grupos de parientes que se valen de ellos para la construcción y fortalecimiento de su supremacía $^{69}$. Los estrechos lazos interpersonales de alguaciles, fieles, escribanos, alcaldes y regidores $^{70}$, entre los que sobresale la presencia de hermanos, hijos y padres, suegros y yernos, así como las relaciones de afinidad y de clientela expresan las formas en que la oligarquía urbana distribuye las cuotas de poder. La acumulación de cargos y la alternancia de los mismos personajes entre distintas funciones caracterizan a la elite política del concejo. Si la permanencia durante décadas de algunos regidores pone de manifiesto su sólida posición institucional, la ocupación temporal y variable de las magistraturas también señala el papel destacado, aunque no excluyente, de las instancias políticas locales dentro de las estrategias de proyección social, económica y jurídica ${ }^{71}$.

La trayectoria de Alonso Álvarez de Vergas -es alcalde ordinario en $1443^{72}$ y obtiene el regimiento en $1447^{73}$ - expresa muchas de las tendencias señaladas. Alfonso encabeza uno de los linajes que logra consolidar su posición en la villa a lo largo del siglo XV a partir de la potencia de sus actividades económicas y de la habilidad para vincularse al servicio de la casa nobiliaria ${ }^{74}$. El pleito que mantiene por la herencia de su padre, también regidor y agente del conde, es ilustrativo de las relaciones no siempre armoniosas que establecen estas figuras con los señores. En las distintas circunstancias políticas por las que atravesó el señorío de Valdecorneja, las lealtades de los oficiales locales son permeables a un sentido de la oportunidad que podía llevarlos a quebrarlas.

En 1488, Alonso de Vergas reclama al duque de Alba don Fadrique la indemnización por "unas alcayçerías, que son tiendas de paños, en la feria" 75 , que hiciera su padre Alonso Álvarez, y que "su señoría el duque, nuestro señor, por enojo que ovo del dicho Alonso Álvarez ge las mandó tomar" ${ }^{\prime 76}$. Si bien el proceso se sigue ante el consejo del duque, se instruye a las distintas justicias de los concejos del señorío para que reciban testimonios y probanzas sobre este asunto; de allí la serie de testigos, todos ellos individuos notables del común, presentados por el demandante.

${ }_{67}$ No pareciera que a comienzos del siglo XV los oficios ya tuvieran un carácter vitalicio, sino que gradualmente este se va imponiendo hasta concluir en la institucionalización de su posesión a perpetuidad en 1464, Luis López, "Estudio", p. 54.

68 En el caso de los Vergas, constituye una novedad dentro del siglo XV la concesión señorial vitalicia y transferible de las regidurías, Calle Sánchez, Estudio jurídico-económico, p. 330.

${ }_{69}$ Como sostiene Jara Fuente, la elite urbana de poder para ser tal debe controlar las formas de acceso al regimiento y su integración, Concejo, poder, elites, p. 120.

70 La "relación, no siempre completa, de las personas que ocuparon los distintos oficios del concejo de Piedrahíta desde el año de 1444 hasta el de 1473", ejemplifica con claridad este aspecto, Piedrahíta, vol. IV, Anexo, V, pp. 222-226.

71 Véase Sánchez Benito, "El poder en una pequeña ciudad", nota 76.

72 Piedrahita, vol. I, doc. 93, p. 251 (1443, enero 11).

73 Piedrahita, vol. II, doc. 2, p. 42(1448, marzo 27).

74 Calle Sánchez, Estudio jurídico-económico, p. 329. Tal como constata este autor, Alonso ejerce el oficio con anterioridad al secuestro del señorío, durante el período de reversión a la Corona y luego de la devolución a los Álvarez de Toledo, Ibidem, p. 375.

75 "Las quales alcayçerías es notorio a todos los de aquella tierra averlas fecho Alfonso Álvarez" (1488, octubre, 01), Piedrahita, vol. V, doc. 35, p. 95.

76 Idem. 
Los años de inestabilidad que provocan la confiscación de las villas y su recuperación por García Álvarez de Toledo, aún en tiempos de la prisión de su padre, dañaron el vínculo con Alonso Álvarez. Así consta en el testimonio de Pedro Ruiz "que el duque don Garçía, nuestro señor (...) tomó las dichas alcayçerías al dicho Alonso Álvarez, porque se puso fuera de la villa contra el dicho señor duque"77. También el zapatero Caçime afirma que "conosçió ser señores desta villa e los vezinos e moradores della ser vasallos destos señores, e que a Alonso Álvarez que le conosçió en esta villa ser rregidor e onbre de mucha onrra"78. En favor de los querellantes, Caçime sostiene que "en tiempo de la prisión del señor conde (...) dos años antes que el señor don Garçía veniese a tomar la tierra le vio al dicho Alonso Álvarez tener e poseer las dichas alcayçerias" 79 .

El objeto del reclamo, que se remonta al pasado, y las situaciones que rodean la inicial desavenencia permiten apreciar la capacidad de las familias dirigentes de la villa de elaborar sus propias estrategias en defensa de sus intereses patrimoniales, aún cuando ello implique aprovechar coyunturas favorables en perjuicio de sus superiores ${ }^{80}$.

Sin embargo, el enfrentamiento original y el incidente judicial posterior no afectan la trayectoria de los Vergas, que no solo mantienen sus posiciones en el concejo sino que refuerzan el servicio a la casa señorial ${ }^{81}$. A lo largo del litigio, el esmerado empleo del lenguaje vasallático pone en evidencia el cuidado con que Álvarez de Vergas pretende dirimir la cuestión sin poner en riesgo sus relaciones con el duque. Sus hijos, como veremos, tienen un derrotero político similar. Por caso, Pedro de Vergas es alcalde en $1448^{82}$, regidor junto a su padre en $1449^{83}$, lugarteniente del corregidor un año después ${ }^{84}$; se oscurece su presencia documental entre 1461 y 1465 , reapareciendo luego como alcalde ordinario ${ }^{85}$, oficio que deja temporalmente por orden del conde dos años más tarde ${ }^{86}$, para retornar a él en $1470^{87}$ y actuar nuevamente como regidor entre 1472 y $1478^{88}$.

No son estos ejemplos aislados; así vemos a Pedro de Bárcena desempeñarse como alguacil en $1457^{89}$, alcalde ordinario entre 1467 y $1470^{90}$ y durante casi dos décadas como regidor de la villa, entre 1471 y 1499 por lo menos ${ }^{91}$; o a Fernando Valdenegro, que también oficia como alcalde en $1477^{92}$ y como regidor desde $1484^{93}$.

\footnotetext{
77 Ibidem, doc. 42, p. 104 (ca. 1488, octubre).

78 Ibidem, p. 103.

79 Idem.

80 Sánchez Benito señala para el caso de Huete que la estrecha vinculación a los nobles de los notables locales no inhibe la competencia con ellos, "El poder en una pequeña ciudad", p. 194.

${ }^{81}$ Los cuatro hijos varones de Alfonso - García, Rodrigo, Pedro y Alonso- desempeñan funciones en la administración concejil y dentro de la casa señorial, trayectoria seguida por algunos de sus nietos.

82 Piedrahita, vol. II, doc. 2, p. 42 (1448, marzo 27).

83 Ibidem, doc. 8, p. 54 (1449, junio 11).

84 Ibidem, doc. 14, p. 67 (1450, abril 17).

85 Tena García, Las finanzas de un concejo, vol. V, p. 196.

86 "Por mandamiento del conde (...) quitó Ferrando Girón, alcalde, la vara del alcaldía a Pero de Vergas e la dieron a Pero de Várzena", Piedrahita, vol. IV, Anexo, V, p. 226.

87 Ibidem, doc. 2, p. 30 y ss. (1466, marzo 04).

88 Ibidem, doc. 61, p. 113 (1472, marzo 06), y doc. 114, p. 207 (1478, noviembre 25), entre otros.

$89 \quad$ Ibidem, p. 224.

90 Ibidem, doc. 17, p. 47 y ss. (1467, febrero 28); Piedrahíta, vol. V, doc. 21, p. 77 (1488, agosto 23), entre otros.

91 Piedrahita, vol. IV, doc. 59, p. 110 (1471, junio 06).

92 Ibidem, doc. 101, p. 180 (1477, enero 17).

93 Piedrahita, vol. V, doc. 6, p. 54 (1484, mayo 22).
} 
La regularidad que adquiere la concentración de los cargos por las mismas personas señala una diferencia significativa respecto de la explícita prohibición regia de estas prácticas en los concejos de realengo ${ }^{94}$. El desempeño de múltiples funciones da cuenta de las modalidades que asume en Piedrahíta el control exclusivo por la minoría privilegiada del órgano municipal. La pluriactividad de los oficiales principales puede ser indicio de una organización política local más simple y de una diferenciación menos sistemática de las tareas técnicas de gestión respecto de aquellas consideradas estrictamente políticas ${ }^{95}$. En este sentido y como veremos en el siguiente apartado, muchos regidores, que exhiben un exhaustivo conocimiento de las responsabilidades y procedimientos administrativos ${ }^{96}$, se comprometen personalmente en la ejecución de las medidas adoptadas por el ayuntamiento, en detrimento del desarrollo de una estructura especializada más amplia de oficios subalternos, sujetos a su autoridad ${ }^{97}$.

Por otra parte, si bien el carácter privilegiado de quienes integran el cuerpo concejil los proyecta como una elite claramente diferenciada, las funciones que ejercen no actúan como factor exclusivo de jerarquización ${ }^{98}$. En la medida en que las resoluciones se encuentran sujetas a la aprobación del conde, de quien en muchas oportunidades los oficiales actúan como sus voceros, la instancia política local no constituye el escenario excluyente de elaboración de los flujos decisionales. Como hemos señalado, con esto no queremos afirmar que la oligarquía piedrahitense es impotente ni despreciar su papel en la dinámica de la comunidad. De lo que se trata es de precisar la incidencia efectiva de la institución municipal en la dirección de los asuntos colectivos e identificar los factores que configuran la preeminencia de los regidores. Respecto de esta cuestión, Monsalvo Antón afirma que era "tan difícil alcanzar una regiduría, un cargo para toda la vida, y recaía tanto poder e influencia en el organismo de gobierno" que por ello "ser o no ser regidor marcaba el éxito o el fracaso en la carrera política de un caballero urbano"

No obstante, la ocupación de posiciones institucionales no configura la única fuente de poder social de los caballeros ${ }^{100}$. El servicio al señor, con sus consecuentes beneficios simbólicos y patrimoniales, no solo está al alcance de los personajes des-

94 "Que los regidores e otros officios que han de ver fazienda del concejo que no puedan aver mas de un officio enel dicho concejo e si tomare otro officio que pierda el que primeramente tenia e nunca lo aya ni tenga mas", Ordenanzas Reales de Castilla, lib. VII, tit. II, ley XIX, p. 280

95 Monsalvo Antón sostiene que a "diferencia de otros oficios concejiles, que responden únicamente a una división social del trabajo político, los regidores locales responden también a una división social del trabajo político sostenida por la división de la sociedad en clases.", El sistema político concejil, p. 226.

96 Aspecto que se aprecia en la documentación municipal y que también ha sido destacado por de la Calle Sánchez, Estudio jurídico-económico, p. 375.

97 La toma de decisiones vinculantes sin la "mediatización de un personal político profesionalizado", en Monsalvo Antón, El sistema político concejil, p. 226. Ceballos-Escalera Gila enfatiza el papel de la "fidelidad y la lealtad incondicional" por encima de la cualificación profesional de los oficiales, "Un linaje de criados", p. 386.

98 En este punto debe tenerse en cuenta la escasa definición de las responsabilidades de los regidores, Asenjo González, "Urban System", p. 37.

99 Monsalvo Antón, "Torres, tierras, linajes", p. 168.

100 Sánchez Benito señala que el cargo de regidor no alcanza para “consolidar posiciones de poder", en tanto la “élite local cimentaba su influencia, como en todas las ciudades, en la propiedad, el prestigio, así como la amplitud y relevancia de sus linajes (...) pero la fluidez del sistema era tan grande que tenían que competir sin pausa si querían consolidarse y eso les ponía en manos de los nobles", "Algunas consideraciones", p. 200. 
tacados sino que resulta crucial en muchas de las trayectorias observadas ${ }^{101}$. Especialmente aquí, como señala Jara Fuente, pareciera que "ser regidor no basta..."102.

\section{Entre el señor y la comunidad}

En su labor cotidiana, los oficiales abordan diversas cuestiones de la vida comunitaria, desde la elevación de peticiones al señor, la regulación de los aprovechamientos agrarios, la administración del patrimonio concejil, hasta los asuntos fiscales que concentran la atención prioritaria del ayuntamiento. Las formas de intervención de los regidores en el tratamiento de estos temas y las tareas que se les confían conducen la reflexión hacia las cualidades de la gestión municipal dentro del marco señorial.

En tiempos de la confiscación del señorío, Alonso de Cáceres, hijo de uno de los oficiales más prominentes de Piedrahíta, Fernando Martínez de Cáceres, es nombrado regidor por el príncipe don Enrique: "presentó el dicho Alonso una carta de nuestro señor, el prínçipe, de merçed que le fizo del rregimiento que vacó por muerte de Diego del Alameda" 103 . Sin embargo, la resolución del grave conflicto en las altas esferas del reino, con la consiguiente ratificación del señorío de los Álvarez de Toledo sobre sus villas ${ }^{104}$, no afecta negativamente a este personaje; por el contrario, su desempeño en la regiduría se constata hasta 1460, momento en el cual comienza una diligente carrera al servicio del señor que afianza su preeminencia. Ejemplos como este dan cuenta del margen de autonomía relativo de la elite concejil respecto del poder superior al que deben responder.

Dentro de las diversas tareas que cumple Alonso como regidor, en 1459 Fernando Álvarez de Toledo lo designa su recaudador de las "alcabalas e terçias et pechos et derechos de la dicha mi villa" ${ }^{105}$. Cuatro años más tarde, lo nombra oficial de su casa $^{106}$, siendo alcaide de la fortaleza desde 1464, en reemplazo del ahora regidor Pedro de Aranda ${ }^{107}$; desde este momento y hasta comienzos de la década de 1490 ocupa el regimiento y la alcaidía, respectivamente ${ }^{108}$. La tarea fiscal encomendada es clave para la realización de los intereses señoriales, a la vez que supone beneficios anexos para quien la lleva a cabo.

En ocasión del cobro del pedido correspondiente al año $1464^{109}$, el conde ordena al concejo que realice un repartimiento para "tasar e derramar los çinquenta e syete

101 La complejización de los estados señoriales se expresa en "un nutrido y amplio aparato de individuos encargados del servicio del señor en todos los ámbitos", Calderón Ortega, "La hacienda de los duques de Alba", p. 153.

102 Jara Fuente, Concejos, poder, elites, p. 106. En el mismo sentido, Sánchez Benito, si bien sostiene que las magistraturas municipales constituían un beneficio del que los personajes principales podían sacar provecho, matiza su eficacia como medio para la proyección política, "El poder de una pequeña ciudad”, pp. 192 y 211.

103 Piedrahíta, vol. II, doc. 11, pp. 60-61 (1449, diciembre 31). El carácter vitalicio de los cargos se advierte en el caso de Diego del Alameda, quien ocupa la regiduría hasta su muerte, Piedrahita, vol. I, doc. 37, p. 174 (1435, enero 01) y Piedrahíta, vol. II, doc. 8, p. 54 (1449, junio 11).

104 Véase la concordia del 14 de diciembre de 1451, Calderón Ortega, "Los riesgos de la política", p. 49.

105 Piedrahita, vol. II, doc. 158, p. 294 (1459, septiembre 20).

106 Piedrahita, vol. III, doc. 75, pp. 111-112 (1463, diciembre 19). La integración de algunos miembros de las oligarquías de las villas a la casa señorial ha sido destacada por Ceballos-Escalera Gila, "Un linaje de criados", p. 389.

107 Piedrahita, vol. III, doc. 99, p. 150 (1464, septiembre 16).

108 Piedrahita, vol. V, doc. 6, p. 54 (1484, mayo 22); Ibidem, doc. 66, p. 148 (1491, octubre 22).

109 Los servicios y pedidos constituyen la principal fuente de ingresos de los señores, en tanto sirven para paliar coyunturas financieras delicadas, a la vez que su prolongación en el tiempo configura uno de los abusos señoriales 
mill e quinientos e cuarenta e tres maravedís que copo a la dicha villa e su tierra" $" 110$, incluyendo el pago de "los salarios de los dichos alcalldes e regidores" 111 , por los gastos generados "en ganar çiertos capítulos del dicho señor conde para la dicha villa e su tierra" 112 , por la suma de "seteçientos e doze maravedís"113. Los oficiales facultados para ejecutar las cargas señoriales también demandan el esfuerzo de los contribuyentes para solventar su actividad como representantes de la comunidad ${ }^{114}$; de allí las tensiones que se producen fundamentalmente con los concejos de la tierra, cuyos procuradores negocian limitar los derechos que llevaban.

Los excesos de los agentes encargados de la recaudación provocan un malestar que exige la búsqueda de acuerdos. Así vemos en 1473 las quejas por la actuación del regidor Pedro de Vergas, responsable de la recolección de los tributos señoriales, por cuanto "demandava derechos de entrega a la tierra de los maravedís de los repartimientos" $" 115$, más allá de los acostumbrados. El conflicto se salda con una concordia entre las partes, en la cual se establece que:

el dicho rrecabdador que agora es e el que por tienpo fuere que non pueda llevar de derechos de todo el rrepartimiento (...) salvo treynta maravedís al millar de yantar e chapines e alcavala del pan e mostrenco; e que, non pueda llevar nin lleve derechos algunos de las otras cosas que se rreparten con ellos ${ }^{116}$.

Además de la regulación de las retribuciones de los alguaciles que enviare el recaudador, se reprime una práctica informal, pero indudablemente difundida que expresa el agrietamiento del colectivo comunitario. Dado que "algunos malasines de la tierra se entremeten a avisar e ayudar a los serviçiadores e a causa dellos viene grandes dapños a la tierra" 117 , el concejo sanciona que "ninguno nin algunos de la villa nin de la tierra non sean osados de malsinar nin andar con los serviçiadores (...) so pena de IIU maravedís (...) para el conçejo del logar donde fuere el tal malasino o que lo troxere preso e más que reciba acá en la villa sesenta açotes" ${ }^{\prime 18}$. Los procuradores de las aldeas alcanzan el éxito en la protección de los tributarios, comprometiendo en esta empresa a toda la villa ${ }^{119}$

La actuación en el terreno fiscal del ya conocido García de Vergas permite comprender la posición de los oficiales concejiles dentro del marco señorial ${ }^{120}$. Desde mediados del siglo XV, los registros municipales lo muestran como alcalde, em-

habituales, Luis López, La comunidad de villa y tierra de Piedrahita, p. 196 y ss.

110 Piedrahita, vol. III, doc. 96, p. 146 (1464, agosto 07).

111 Ibidem, p. 147. La nómina de los salarios de todos oficiales del concejo correspondientes a este año, en Tena García, Las finanzas de un concejo, vol. V, pp. 141-142.

112 Piedrahita, vol. III, doc. 96, p. 146 (1464, agosto 07).

113 Ibidem, p. 147

114 Sobre el salario de los regidores receptores, Piedrahita, vol. IV, doc. 31, p. 68 (1468, mayo 03).

115 Ibidem, doc. 69, pp. 124-125 (1473, marzo 05).

116 Ibidem, p. 125.

117 Idem.

118 Idem.

119 El protagonismo de la representación aldeana puede apreciarse en distintas intervenciones en torno de los modos de recaudación, por ejemplo Piedrahíta, vol. IV, doc. 31, p. 67 y ss. (1468, mayo 03).

120 Calderón Ortega destaca la gestión de los contadores, pagadores, arrendadores y recaudadores del estado señorial, "La hacienda de los duques de Alba", pp. 164 y 190. 
padronador, recaudador y receptor de los tributos señoriales ${ }^{121}$. Como contador del conde, suscribe en 1465 una iguala con los representantes de la villa y de su tierra por la alcabala del $\operatorname{pan}^{122}$. La dualidad funcional que dota de autoridad a este personaje puede apreciarse en la descripción de la reunión del concejo "a canpana rrepicada", en la que participa como "contador e rregidor"123. En el desarrollo de las deliberaciones, en su calidad de agente señorial defiende la suba del tributo, pues "la dicha alcavala, que estava baxa, de lo qual su merçed açerca dello avía dado cargo al dicho Garçia de Vergas, su contador"124, logrando finalmente el acuerdo para aumentar de quince mil a diecisiete mil maravedís la suma obligada ${ }^{125}$.

La clara ubicación privilegiada que ostenta este caballero dentro de la minoría dirigente local se inscribe dentro de la potencia de su linaje. En la sesión del 22 de diciembre de 1465, García de Vergas presenta la carta de don García Álvarez de Toledo en la cual le concede a su hermano, Alonso, el puesto de alférez de los peones de la villa ${ }^{126}$. La fortaleza de la familia y la preponderancia de este regidor en particular dan cuenta de la jerarquización de la oligarquía urbana, estrechamente ligada a los vínculos que algunos de sus miembros establecen con el titular señorial.

La figura de Ferrand Blázquez Guerra también es representativa de las características de los grupos oligárquicos. Procedente de un linaje prominente, es hijo del regidor Alonso Guerra y hermano de Pedro, quien fuera por más de una década alcalde de la villa; su extensa trayectoria en el concejo abarca su intervención en la gestión fiscal como receptor de los pedidos y monedas solicitados por el rey ${ }^{127} \mathrm{y}$ recaudador del titular jurisdiccional ${ }^{128}$. En 1454 se le encomienda la recolección del servicio extraordinario impuesto sobre la villa y su tierra, en su condición de secretario $^{129}$ y criado del conde ${ }^{130}$. Aparece ocupando la alcaldía ocasionalmente en 1412 y $1456^{131}$, mientras sigue activamente comprometido con las tareas fiscales ${ }^{132}$, en las que continúa involucrado por más de una década ${ }^{133}$.

El estatus desigual de los caballeros que ocupan las regidurías tiene una expresión simbólica en torno de la tenencia de las llaves de las cinco puertas de la muralla de la villa ${ }^{134}$. El menor número de llaves que de regidores actúa como factor de decantación elitista dentro de la propia oligarquía; de allí que solo los mejor posicionados, como es el caso de Blázquez Guerra, accedan a este privilegio ${ }^{135}$. La

121 Como recaudador de diezmos, Piedrahita, vol. II, doc. 50, p. 118 (1452, agosto 19).

122 "Yguala que se fizo entre el conçejo e alcayde e alcalldes e regidores e procuradores de la villa de Piedrafita con Garçía de Vergas, contador de nuestro señor el conde, e en nonbre de su merçed, sobre el alcavala del pan" (1465, marzo 21), Piedrahita, vol. III, doc. 117, p. 172.

123 Idem.

124 Idem.

125 Ibidem, p. 173

126 Piedrahita, vol. III, doc. 134, p. 190.

127 Piedrahita, vol. II, docs. 30, 35 y 36. Sobre los procedimientos administrativos para gestionar las exacciones regias en el marco del señorío de Valdecorneja, Ser Quijano, "Fiscalidad real y señorial", pp. 247-248.

128 Piedrahita, vol. II, docs. 43, 44, 53, 88, 89 y 98.

129 Ibidem, doc. 86, p. 200 (1454, octubre 12).

130 Ibidem, doc. 87, p. 201 (1454, noviembre 21).

131 Piedrahita, vol. IV, Anexo, doc. V, p. 224.

132 Piedrahíta, vol. II, doc. 99, p. 221 (1456, marzo 06); Ibidem, doc. 102, p. 228 (1456, mayo 19).

133 Ibidem, doc. 151, p. 285 (1459, abril 24). Ya como regidor también es nombrado recaudador del servicio del conde, Piedrahita, vol. IV, doc. 4, p. 34 (1466, abril 12).

134 Santos Canalejos, "Piedrahíta", p. 1145.

135 "Ferrand Blázquez Guerra, rregidor, vecino de la dicha villa, e dixo que por quanto la llave de la puerta de la Forcajada estava vaca por muerte e vacaçión de Sancho González, rregidor (...) en la qual estava mala guarda, 
cercanía con la casa nobiliaria constituye un eficiente estímulo para la promoción social y política. Francisco Girón, criado del conde, es favorecido con la regiduría y la llave correspondiente que dejara vacantes tras su fallecimiento Fernando Martínez de Cáceres ${ }^{136}$, yerno de García de Vergas ${ }^{137}$. En este caso, aunque Girón pertenece a una familia bien emparentada y con una ubicación favorable dentro de la oligarquía local, la provisión del oficio responde directamente a la decisión señorial, al igual que la designación de su hermano, Rodrigo Girón, primero como alcalde y luego como alguacil de la villa; cargo este último que debe delegar para prestar servicio al duque de Alba en el castillo de Montalbán ${ }^{138}$.

Personajes como estos encarnan la referida dualidad de la minoría dirigente concejil, en tanto agentes señoriales y oficiales locales. Este aspecto sustancial no resulta exclusivamente del origen de sus designaciones sino fundamentalmente de sus prácticas. La gestión de regidores y alcaldes se encuentra condicionada por la necesidad de garantizar el dominio señorial, preservar la estabilidad de la comunidad a la cual rigen, así como por la defensa de sus propios intereses como segmento privilegiado.

La lógica servicial que enlaza a los miembros del concejo con el titular jurisdiccional se expresa particularmente en la administración de la fiscalidad; pero también, en este plano, deben evitar el menoscabo de las bases sociales de la villa, pese a que muchas veces son ellos quienes las dañan. En este sentido, las constantes negociaciones con los representantes de la tierra en torno de las diferentes imposiciones tributarias dan cuenta de la ineludible lógica transaccional que atraviesa la actividad regimental ${ }^{139}$. Al mismo tiempo, la pertenencia a las familias más poderosas de Piedrahíta y dentro de ellas a las que ostentan la autoridad política orienta las acciones de estas figuras hacia la consolidación de su estatus, motivando en ocasiones el rechazo de los pecheros y la ulterior intervención del conde para remediarlo ${ }^{140}$.

$\mathrm{Si}$ el doble papel funcional como dirigentes concejiles y agentes señoriales constituye un rasgo distintivo de estos oficiales, la búsqueda de beneficios particulares, valiéndose de sus posiciones dentro de la administración local, también merece señalarse. Los miembros de la elite no solo gozan de autoridad institucional para gestionar la tributación, sino que a su vez intervienen en ella como actores privados con evidente solidez patrimonial. Así, el regidor García de Vergas obtiene el remate de la renta de la alcabala

por non aver quien cargo della tuviese. E todos los otros regidores, que puertas tenían, tenían sus llaves dellas (...) dixeron que, por quanto demandava cosa justa, la qual se le devía de dar" (1464, septiembre 16), Piedrahita, vol. III, doc. 99, p. 151; "por quanto Rrodrigo de Medina, rregidor que era de la dicha villa, cuya ánima Dios aya, es falleçido de la presente vida, el qual tenía la llave de la puerta del Postigo(...)mandavan que el dicho Ximón Gonçález de Plasençia, rregidor, tenga la dicha llave (...) porque él non tenía llave alguna conmo los otros regidores" (1467, febrero 28), Piedrahita, vol. IV, doc. 17, pp. 47 y 48.

136 Piedrahita, vol. III, doc. 11, p. 45 (1461, octubre 14).

137 Piedrahita, vol. IV, Apéndice, doc. V, p. 226.

138 Ibidem, doc. 46, p. 91 (1470, enero 05).

139 Dado el estado de necesidad que atraviesan los concejos de la tierra, se reúne el concejo de la villa con los procuradores de los pueblos en "unas casas que son del contador, Garçía de Vergas", en los arrabales de Piedrahíta, para revisar el repartimiento efectuado y modificar el número de pecherías, atendiendo a "las muertes e pestilencias que han acaesçido" (1470, marzo 22), Ibidem, doc. 48, p. 94.

140 Una provisión del conde de Alba de 1464 prohíbe los gastos excesivos del concejo "quando se toma la cuenta al mayordomo de conçejo, se ayuntan muchos al comer della e se come un yantar en que se gastan muchos dineros de las rrentas del conçejo (...) non se ayunten al tomar della sy non los regidores que estuvieren en la dicha villa e los allcalldes e alguazil e un escribano e fieles e dos escuderos e dos labradores e non más, e el procurador e mayordomo (...) e non se coma la dicha yantar" (1464, enero 12), Piedrahita, vol. III, doc. 77, p. 114; medidas de austeridad similares en el concejo de Huete, Sánchez Benito, "El poder en una pequeña ciudad”, p. 180. 
del pan, en condiciones indudablemente favorables: "dio Garçía de Vergas, rregidor, por ella tres mill maravedís, en el qual rremató por los dichos tres mill maravedís, por quanto no ovo quién tanto nin más diese por ella"141. La situación privilegiada de este oficial sobre la que hemos insistido en estas páginas se combina con su activa participación en los negocios más lucrativos. No obstante, en algunas circunstancias prevalece en sus conductas su carácter de oficial concejil, en tanto la instancia colectiva debe procurar mantener los equilibrios locales, evitando confrontar con los grupos económicamente más pujantes del común. Así interpretamos la decisión de García de Vergas de abstenerse de participar de la puja de la carnicería de la villa ${ }^{142}$.

Del mismo modo, resulta significativa la política de tierras del concejo. La regulación de los aprovechamientos individuales y la protección de los recursos comunales aparecen desde temprano en la normativa municipal. El ordenamiento sobre montes y pinares de $1405^{143}$ pretende defender estos espacios de las acciones lesivas que emprenden muchos de sus vecinos ${ }^{144}$, entre los cuales sobresalen

algunos rregidores e escuderos, vecinos de la dicha villa e su tierra, [que] echan en la dicha dehesa, poderosamente, non temiendo a Dios nin al señor nin a la justiçia, sus bestias, así cavallos conmo mulas e potros, a paçer en la dicha dehesa syn pastor que los guarde, e comen los panes e prados agenos ${ }^{145}$.

El margen de autonomía del concejo respecto del titular jurisdiccional se advierte en la capacidad de privar de sus cargos a quienes no hicieran cumplir las disposiciones sobre asuntos vitales como estos ${ }^{146}$. Sin embargo, el control del aparato político local por la elite de caballeros no solo está condicionado por el poder superior, sino que debe sortear los desafíos que recibe desde abajo. El creciente protagonismo de los sectores enriquecidos del común que aspiran a acceder a ciertos puestos concejiles actualiza la rivalidad con la minoría regimental, tal como sucede en 1464 a propósito de las peticiones elevadas al conde de Alba respecto de los usos, libertades y franquezas de la villa ${ }^{147}$.

Si las disputas internas nos permiten advertir la capacidad de acción de los diferentes grupos sociales, los litigios con los vecinos señoriales ponen en evidencia la subordinación de la estructura comunitaria a la casa dominante. En este plano, el

141 Piedrahita, vol. II, doc. 97, p. 218(1456, marzo 05).

142 "El dicho Garçía de Vergas dixo que porquél avía fablado en la dicha carneçería e los dichos regidores non se conçertavan con Juan Garçía, carniçero, e otro ninguno non se podía fallar, que jurava e juró a Dios e a Santa María de non fablar en la dicha carneçería este dicho año" (1461, abril 05), Piedrahíta, vol. III, doc. 3, p. 36.

143 Sobre el particular, Colombo, "Producción campesina y poder concejil en Piedrahíta".

144 Varias décadas después, en 1466, la leña del monte sigue siendo objeto de prácticas rapaces con las consiguientes intervenciones para castigarlas: "más los maravedís que montaren en las penas de los que han cortado leña en el monte de La Jura (...) que non se dio por quanto non estava aquí Ximón de Plasençia, rregidor e guarda del dicho monte", Tena García, Las finanzas de un concejo, vol. V, p. 203.

145 Piedrahita, vol. I, doc. 6, p. 95 (1405, noviembre 22).

146 "Cualquier alcallde o alguazil que lo así non quisiere fazer e conplir, pierda el ofiçio que toviere ese año, e que torne la soldada (...) e si el señor non fuere en la tierra, que el conçejo que les pueda privar del tal ofiçio" (1405, noviembre 22), Ibidem, doc. 6, p. 96.

147 "Que vuestra señoría dará los ofiçios de alcaldías e alguaziladgo e fialadgos a los escuderos de la dicha villa a suplicaçion, e cada año, del dicho conçejo; e çerca de las alcaldías (...) que sean dadas a personas suficientes e tales que guarden vuestro serviçio e bien e pro de la dicha villa e de su tierra (...) e los fialadgos, que solían ser dados a los más honrrados de la dicha villa, e, agora señor, andan abatydos en personas comunes, e en ellos es grand parte del rregimiento de la dicha villa(...)suplicamos provea en ello, mandándolo al estado en que antes era" (1464, mayo 16), Piedrahita, vol. III, doc. 83, pp. 125-126. 
conde interviene en el juego político que involucra a otros señores, con los que coopera tanto como compite. El pleito que Valdecorneja sostiene con el obispo de Ávila Juan de Guzmán a comienzos del siglo XV, por razón de las respectivas ordenanzas que afectaban la preeminencia jurisdiccional, se desarrolla en los distintos niveles de la organización señorial. Por un lado, los concejos de ambos señoríos individualmente consienten la designación de jueces árbitros; por otro, son los propios titulares señoriales quienes firman el compromiso para otorgar poder al bachiller Pero González de Bonilla, vecino de Salamanca y al bachiller García Martínez, vecino de Ávila "por nuestros alcalldes, amigos, actores, arbitradores, conponedores, conprometedores, para que libren entre las dichas partes los dichos pleitos"148.

El alcance de esta disputa entre señoríos está dado por la relevancia de sus protagonistas; sin embargo, más allá de su resolución concreta luego de la sentencia otorgada con notable premura un par de días después de iniciadas las demandas ${ }^{149}$, interesa destacar la figura de Gonzalo García, quien oficia a la vez como procurador de la viuda del duque de Alba, doña Constanza Sarmiento, y de cada uno de los concejos que integran Valdecorneja ${ }^{150}$. La anulación práctica de la capacidad de actuación de las distintas villas en las instancias judiciales más elevadas se torna evidente. No obstante, si bien el nombramiento del procurador por parte de los oficiales locales, en armonía con la estrategia del señor, pareciera ser una mera formalidad, la permanencia de ese procedimiento no deja de ser significativa, en la medida en que, desde el punto de vista institucional, no cancela la potestad decisional del concejo.

Pero volvamos al ámbito de la comunidad y a la sistemática conflictividad por la tierra. El concejo de Piedrahíta interviene tanto en las normas generales sobre el usufructo de los términos comunes como en las numerosas operaciones de transferencia de suelos que efectúa con particulares ${ }^{151}$; en ambos casos, se trata de mantener un equilibrio entre la instancia de regulación colectiva y los intereses de los propietarios más importantes de la villa, que ocupan a su vez posiciones institucionales. En 1401, Miguel Sánchez, hijo del regidor Gonzalo Sánchez y padre del también regidor Martín Fernández ${ }^{152}$, vende al concejo de Piedrahíta unas tierras de pan lindantes con la dehesa concejil de Navacavera ${ }^{153}$. El pago que obtiene Sánchez es muy beneficioso, pues se le otorga el usufructo de toda la dehesa por un período de seis años: "damos a vos, el dicho Miguell Sánchez, la rrenta que rendiese la dicha Navacabera por seys años (...) para que lo ayades para vos e para vuestros herederos"154, aunque se establece la limitación de "que non derronpades en la dicha defesa e heredat para labor por pan más de lo que agora está derroto"155.

Los distintos actos de compraventa y de traspaso de tierras permiten observar las estrategias patrimoniales de la villa y de las familias que ocupan las magistraturas

148 Piedrahita, vol. I, doc. 23, p. 143 (1412, agosto 06).

149 Ibidem, p. 148.

$150 \quad$ Ibidem, p. 142.

151 Las "numerosas ventas y arrendamientos realizados en tierras y baldíos de las villas del estado señorial" son una sustanciosa fuente de ingresos para la casa nobiliaria, Calderón Ortega, "La hacienda de los duques de Alba", p. 146.

152 Véase Calleja Puerta, Las finanzas de un concejo, vol. I, p. 56.

153 Los recursos que produce la dehesa de Navacavera y los baldíos colindantes en Calleja Puerta, Las finanzas de un concejo, vol. I, pp. 55-56; su renta asciende en 1438 a 4200 mrs., Ser Quijano, Las finanzas de un concejo, vol. II, p. 71.

154 Piedrahita, vol. I, doc. 5, p. 90 (1401, noviembre 03).

155 Idem. 
principales ${ }^{156}$. En 1445, Rodrigo Álvarez de Montoya ${ }^{157}$, regidor de Piedrahíta y alcaide del castillo del Barco, vende al concejo una huerta por valor de $2.000 \mathrm{mrs}{ }^{158}$. En 1460, es el ayuntamiento el que resuelve otorgar al regidor Fernando González de Montenegro la suma de 350 maravedís en compensación por haberle tomado parte de su tierra para abrir un camino ${ }^{159}$. También Francisco Girón a los pocos años de asumir la regiduría vende "un pedaço de tierra para camino e entrada desta dicha villa" ${ }^{160}$, apreciada en un valor de $3500 \mathrm{mrs}$. En todos los casos, tanto la villa como los propietarios privilegiados parecen favorecerse.

Por su parte, la superioridad patrimonial del regidor García de Vergas se observa en los montos de la operación realizada con el vecino de Alba de Tormes, Gonzalo Brochero, quien le vende las diversas propiedades y recursos que tenía por herencia en el término de Piedrahíta, más la mitad de unas casas situadas en la villa, por un total de $34.000 \mathrm{mrs}$. libres de alcabala ${ }^{161}$. La activa política de acumulación fundiaria, común a todos los miembros de las oligarquías castellanas, se apoya en este caso en la doble condición de servidor del conde y oficial concejil ${ }^{162}$; dualidad de la que se deriva un diferencial de poder respecto de sus pares regimentales ${ }^{163}$.

Si todos los regidores disponen de fortuna, gozan de privilegios y de una ubicación preferencial en la dinámica de toma de decisiones comunitarias ${ }^{164}$, la situación de García de Vergas como delegado señorial lo eleva por encima de la minoría urbana ${ }^{165}$. Su designación para tomar el juramento de fidelidad al conde ${ }^{166}$, en ocasión de la confirmación de los oficios municipales, pone de manifiesto una vez más la relevancia de este personaje y su papel articulador entre el concejo y la jurisdicción superior: "ayuntados a conçejo (...) Garçía de Vergas les tomó en la señal de la cruz, en forma devida, que bien e leal e verdaderamente conplirían las cartas e mandamientos del dicho señor conde e guardarían el pro e bien de la rrepública"167. El ascenso social y político resultante del servicio al señor se expresa de manera modélica en el recorrido de esta figura ${ }^{168}$.

156 Así en 1467, los herederos de Ferrand González de Montenegro truecan un trozo de tierra por otro perteneciente al concejo, Piedrahita, vol. IV, doc. 25, p. 59 (1467, diciembre 19); y unas semanas después permutan otros suelos por parte del ejido concejil, Ibidem, doc. 28, p. 62 (1468, enero 04).

157 Había sido ya corregidor de Piedrahíta y "rreçebtor que fue de los maravedís que rrendió el cornado de la çerca", (1433 y 1434), Calleja Puerta, Las finanzas de un concejo, vol. I, p. 280.

158 Piedrahita, vol. I, doc. 113, pp. 277-278 (1445, agosto 05).

159 Piedrahita, vol. II, doc. 175, p. 312 (1460, mayo 25).

160 Piedrahita, vol. III, doc. 63, p. 95 (1463, enero 23).

161 Piedrahita, vol. IV, doc. 104, p. 189 (1477, abril 10).

162 La importancia de los espacios obtenidos por el favor señorial o regio en la conformación del patrimonio de estas oligarquías en Calle Sánchez, Estudio jurídico-económico, p. 335.

163 García de Vergas realiza operaciones ventajosas con el concejo, como aquella en la que obtiene del ayuntamiento "un pedaço de tierra que está cabe su rroça para sacar la pared de la dicha rroça e meterlo dentro (...) para él e para sus herederos" (1462, diciembre 04), Piedrahita, vol. III, doc. 56, p. 89.

164 Como señala Monsalvo Antón, la "sociedad local tiene plena conciencia del poder de los regidores, que excede su estricto poder político en el aparato concejil para extenderse a otros ámbitos", El sistema político concejil, p. 224.

165 La "promoción de individuos y grupos dentro de las oligarquías urbanas y la defensa de sus intereses en un marco local o regional a través de los señores", ha sido destacada en el reciente trabajo de López-Guadalupe Pallarés, "Procesos de señorialización", p. 445.

166 "Mando que fagades el dicho juramento, ayuntados en vuestros conçejos, en manos de Garçía de Vergas" (1464, diciembre 22), Piedrahita, vol. III, doc. 105, p. 157.

167 Ibidem, doc. 107, p. 159 (1464, diciembre 27).

168 Sobre el papel del servicio al señor en la proyección sociopolítica de algunas figuras concejiles y de sus respectivos linajes, Lozano Castellanos, "E por muchas obras”, p. 324 y Monsalvo Antón, “Arraigo territorial”, p. 142. 
El estudio de los oficiales concejiles permite advertir la existencia de individuos que trascienden el ámbito local para desplegar sus actuaciones dentro de un espacio social más amplio. De este modo, junto a aquellos que se destacan como un segmento encumbrado de la elite de la villa, aparecen otros que proyectan su influencia sobre los demás concejos del señorío ${ }^{169} \mathrm{o}$ bien que alcanzan posiciones en las esferas más altas del reino ${ }^{170}$. Como hemos señalado, la riqueza, el acceso a los cargos municipales y la cercanía a la familia ducal son factores claves en la consolidación de esta minoría, pero la promoción de los integrantes de cada linaje está dada por el empleo inteligente de los distintos recursos de poder con los que cuentan. En este sentido, la diferenciación interna de la elite responde a las diversas combinaciones de estas variables.

\section{Reflexiones finales}

La investigación de las instancias concejiles sometidas al dominio señorial, lejos de ser una cuestión saldada, constituye un problema abierto a nuevas elaboraciones. La profundización de estudios de caso, así como el esfuerzo por comprender en un plano conceptual la relación del poder jurisdiccional privado con las estructuras sociopolíticas locales, forman parte de la agenda de trabajo. En esta colaboración, hemos priorizado el análisis de las prácticas efectivas por sobre el de las características institucionales del nuevo encuadramiento jurisdiccional ${ }^{171}$; prácticas que implican relaciones de fuerzas tanto hacia el interior de la organización comunitaria, como entre esta y su señor. Si "la iniciativa política estaba en manos de la nobleza territorial y no en las del regimiento" 172 , también es cierto que el poder superior debía establecer un diálogo eficaz con los sectores en los que se apoyaba el ejercicio de su dominación ${ }^{173}$.

La condición dual de los oficiales a la que nos hemos referido señala tanto las cualidades del gobierno concejil como de sus grupos dirigentes. Esta modalidad singular de articulación entre la comunidad y el poder noble condiciona la actividad del concejo y de sus elites ${ }^{174}$. La oligarquía villana se encuentra fuertemente atravesada

169 El caso del citado Rodrigo Álvarez de Montoya es ilustrativo: regidor de Piedrahíta desde 1435, ejerce al mismo tiempo como alcaide del castillo de El Barco de Ávila a partir de 1445, Piedrahita, vol. I, doc. 113, p. 277 (1445, agosto 05).

170 Fernando Martínez del Mirón, quien fuera en 1435 “escrivano del rrey por merçed de nuestra señora”, Piedrahíta, vol. I, doc. 49, p. 191, se desempeña como alcalde de la villa -cargo que ejercerá su hijo Juan-y recaudador del conde, Piedrahita, vol. I, doc. 102, p. 262 (1444, febrero 27), y como regidor en 1448, Piedrahita, vol. II, doc. 2, p. 42. Otro alcalde, Alonso Sánchez de la Horcajada, es también escribano del rey y escribano público del concejo de Piedrahíta, Piedrahita, vol. II, docs. 88 y 84.

171 En este sentido, respecto del análisis del poder en los concejos señoriales Monsalvo Antón sostiene que "se trata de cuestiones en torno al poder efectivo, ejercido en la práctica, algo que no se corresponde con las formalidades jurídicas", "Arraigo territorial", p. 139.

172 Sánchez Benito, “Algunas consideraciones”, p. 205.

173 El diálogo permanente del concejo con el señor generó beneficios para la villa, "siempre y cuando las fuentes de ingresos señoriales no se vieran afectadas", Luis López, "Piedrahíta”, pp. 1168-1169.

174 "Los señores (...) generan estructuras organizativas y de oficios o microaparatos, integrados en un sistema personalista-señorial de mando y desconcentración funcional" en el cual se articulan estructuras "supeditadas a lealtades personales y compuestas por oficiales netamente señoriales -servidores, clientes y vasallos caballerescos o nobiliares de rango inferior al del titular del señorío- o por personajes notables a nivel local investidos de atribuciones netamente señoriales", Monsalvo Antón, El sistema político concejil, p. 33. 
por los lazos de sus miembros con la jurisdicción señorial, dentro de un juego de flujos políticos multidireccionales ${ }^{175}$. Sin embargo, los señores de Valdecorneja no imponen su dominio sobre estructuras sociales inertes; por el contrario, construyen un vínculo transaccional, no exento de conflictos, con una comunidad desigual, contradictoria y fundamentalmente dinámica. De este modo, podemos comprender el esfuerzo que la casa de Alba despliega para ganar la lealtad y sujetar a la minoría dirigente comunitaria.

La caracterización de las elites concejiles es indisociable tanto de los procesos de diferenciación social interna como de la inscripción de sus sectores privilegiados en las distintas esferas de toma de decisiones. En otras palabras, la formación y consolidación de la oligarquía villana se encuentran estrechamente ligadas a los respectivos márgenes de acción de la instancia política local y de la jurisdicción superior. La dialéctica entre ambas agencias es clave para reconocer no solo las cualidades de la organización municipal y de sus oficiales, sino las posibilidades de reproducción de la propia comunidad. Esta reorientación del análisis nos permite ensayar una serie de respuestas provisorias a los interrogantes planteados inicialmente.

Los oficiales de Piedrahíta comparten con sus pares de los concejos de realengo de la Extremadura su condición de propietarios privilegiados. La obtención de los puestos principales da cuenta de la capacidad para obtener el favor de los titulares del dominio, a través de distintos vínculos clientelares y de servicio, y del éxito en el proceso de promoción intracomunitaria ${ }^{176}$. Sin embargo, el acceso a las regidurías no determina un punto de llegada; las presiones que desde abajo generan los sectores pecheros más activos y el intento desde arriba de los sucesivos señores de subordinar a la oligarquía, interfieren en este desarrollo.

A su vez, la asimilación a los escalones inferiores de la nobleza de muchos miembros de los linajes urbanos imprime a su actuación como oficiales concejiles un rasgo diferenciado. Sánchez Benito sostiene que a comienzos del siglo XV "tanto la influencia social como la actividad política" de estos grupos "se basaban en vinculaciones de naturaleza privada, escapando por completo al funcionamiento institucional" 177 . Pese a que la potencia de esa trama de relaciones interpersonales por fuera del escenario formal del gobierno comunitario es insoslayable, nos permitimos matizar el carácter taxativo de esta afirmación. El concejo de Piedrahíta es tanto un espacio de elaboración de decisiones como de procesamiento de aquellas que son adoptadas por el poder superior. Sus autoridades son al mismo tiempo correa de transmisión de las políticas del titular señorial y artífices de sus propias disposiciones; todo ello en un contexto en el cual la preservación del orden social exige contener las demandas del común tributario.

Si la caracterización de la instancia de gestión local debe tener en cuenta todos los elementos que hemos desarrollado en estas páginas, la identificación de las cualidades de los oficiales exige el estudio tanto de los factores estrictamente jurídicopolíticos como de aquellos de orden sociológico. La solidez patrimonial, la cohesión y resguardo que ofrecen los lazos de parentesco y de afinidad, el servicio al señor y a su casa son rasgos siempre presentes en las trayectorias de los personajes promi-

\footnotetext{
175 Idem.

176 La situación clientelar de los miembros de la oligarquía urbana que sirven al señor en calidad de regidores, oficiales y letrados en de Ceballos-Escalera Gila, "Un linaje de criados", p. 389.

177 Sánchez Benito, “Algunas consideraciones”, p. 205.
} 
nentes. El control de los distintos oficios, con la consiguiente ubicación preferencial respecto de los procedimientos jurídicos, administrativos y financieros favorece la consolidación de ciertos individuos y de sus familias. Sin embargo, la suerte de estas figuras no está excluyentemente determinada por la disposición de las magistraturas concejiles.

Más que ante una verdadera elite política como las que se han estudiado profusamente en los municipios del realengo, estamos frente a una minoría privilegiada que encuentra en las relaciones personales con la casa dominante un medio significativo para su proyección social. No obstante, esta elite de servicio no puede reducirse a la condición de meros agentes señoriales, en tanto la lógica servicial que orienta muchas de sus prácticas no constituye un fin en sí mismo. Por el contrario, servir al señor configura un medio para el desarrollo y la satisfacción de sus propios intereses.

En rasgos generales, la conformación del grupo dirigente no parece sufrir un cambio sustancial a partir de la señorialización del concejo, en la medida en que la estrategia de los Álvarez de Toledo consiste en una cuidadosa selección de individuos pertenecientes a los linajes que ya ostentan su supremacía para ponerlos a su servicio. Esta dinámica conduce a la segregación y promoción de algunas familias, cuyo poder deviene cualitativamente superior. En este sentido, podríamos decir que son los mismos, pero no son lo mismo. El encuadramiento señorial no desconoce al conjunto de los privilegiados de Piedrahíta ${ }^{178}$, se basa en ellos para dotarlos de una nueva y doble función: regir el concejo y servir al señor.

\section{Bibliografía}

Asenjo González, María, "Urban System as an Oligarchy Structuring Process in FifteenthCentury Castillian Society", en Oligarchy and Patronage in Late Medieval Spanish Urban Society, Turnhout: Brepols, 2009, pp. 29-50.

Bonachía Hernando, Juan Antonio, "El concejo como señorío: Castilla, siglos XIII-XV", en Concejos y ciudades en la Edad Media hispánica: II Congreso de estudios medievales, León: Fundación Sánchez Albornoz, 1990, pp. 429-464.

- y Martín Cea, Juan Carlos, "Oligarquías y poderes concejiles en la Castilla bajomedieval: balance y perspectivas", Revista d'Historia Medieval, 9 (1988), pp. 17-40.

Calderón Ortega, José Manuel, "Los corregidores del duque de Alba (1430-1531), Anuario de la Facultad de Derecho de Alcalá de Henares, 3 (1993-1994), pp. 107-134.

- "Los riesgos de la política en el siglo XV: la prisión del conde de Alba (1448-1454)", Historia. Instituciones. Documentos, 21 (1994), pp. 41-62.

- "El gobierno y la administración de un estado señorial: el Consejo de los Duques de Alba (1434-1531)", En la España Medieval, 19 (1996), pp. 311-346.

- "La hacienda de los duques de Alba en los siglos XV y XVI: ingresos y gastos", Espacio, Tiempo y Forma. Serie III. Medieval, 9 (1996), pp. 137-228.

- Documentación medieval abulense en el archivo de la Casa de Alba, Ávila: Institución Gran Duque de Alba, 2000.

178 La continuidad de los linajes dominantes ha sido detectada también en otras villas de señorío; por ejemplo, en el caso de Cuéllar, "el duque respetó sus estructuras oligárquicas, pero no faltan los personajes consagrados en el concejo o en los oficios concejiles que están relacionados con la casa ducal", López-Guadalupe Pallarés, "Eficacia resolutiva", p. 353, nota 15. 
- El ducado de Alba. La evolución histórica, el Gobierno y la Hacienda de un Estado señorial (siglos XIV-XVI), Madrid: Dykinson, 2005.

Calle Sánchez, Eduardo de la, Estudio jurídico-económico de las ordenanzas y libros de cuentas de la Comunidad de Villa y Tierra de Piedrahita como parte del señorío de Valdecorneja, tesis doctoral inédita de la Universidad Complutense de Madrid, Facultad de Derecho, Departamento de Historia del Derecho, leída el 17/09/2015, [en línea] disponible en https://eprints.ucm.es/33775/1/T36588.pdf

Calleja Puerta, Miguel, Las finanzas de un concejo castellano: Piedrahita, siglos XV-XVI, vol. I, Ávila: Institución Gran Duque de Alba, 2010.

Ceballos-Escalera Gila, Alfonso, "Un linaje de criados mayores de la casa ducal de Alba: los Villapecellín, alcaides de Alba de Tormes y Piedrahíta”, en Gregorio del Ser Quijano (coord.), Actas del V Centenario del nacimiento del III Duque de Alba, Fernando Álvarez de Toledo, Ávila: Institución Gran Duque de Alba, Salamanca: Diputación de Salamanca, 2008, pp. 383-399.

Clemente Ramos, Julián, “Estructura concejil y sociedad feudal, en la transierra extremeña siglos XII y XIII, Hispania, 51/177 (1991), pp. 41-71.

Colombo, Octavio, "Producción campesina y poder concejil en Piedrahíta: la ordenanza sobre la madera de 1405", Actas y Comunicaciones del Instituto de Historia Antigua y Medieval, 9/1 (2013), pp. 1-8, [en línea] disponible en http://www.filo.uba.ar/contenidos/ investigacion/institutos/historiaantiguaymedieval/index.htm/\#actas

Cortes de los antiguos reinos de León y de Castilla, Madrid: Real Academia de la Historia, vols. III y IV, 1866-1882.

Estepa Díez, Carlos, "El realengo y el señorío jurisdiccional concejil en Castilla y León (siglos XII-XV)", en Concejos y ciudades en la Edad Media hispánica: II Congreso de estudios medievales, León: Fundación Sánchez Albornoz, 1990, pp. 465-506.

García Oliva, Dolores, "Señores contra campesinos: un conflicto por la tierra en Mirabel a finales de la Edad Media y principios de los tiempos modernos", Espacio, Tiempo y Forma. Serie III. Historia Medieval, 31 (2018), pp. 303-342.

Goicolea Julián, Francisco Javier, "Sociedad y poder concejil: una aproximación a la elite urbana de la Rioja Alta medieval”, Studia Histórica. Medieval, 17 (1999), pp. 87-112.

Jara Fuente, José Antonio, "Sobre el concejo cerrado. Asamblearismo y participación política en las ciudades castellanas de la baja Edad Media (Conflictos inter o intra-clase), Studia Histórica. Medieval, 17 (1999), pp. 113-136.

- Concejos, poder, elites: la clase dominante en Cuenca en el siglo XV, Madrid: CSIC, 2000.

- "Posiciones de clase y sistemas de poder: vinculaciones y contradicciones en la construcción del «Común de pecheros» en la Baja Edad Media”, en José I. de la Iglesia Duarte, y José L. Martín Rodríguez (coords.), Los espacios de poder en la España medieval, Logroño: Instituto de Estudios Riojanos, 2002, pp. 511-532.

- "Estructuras formales de poder y de organización de las clases dominantes urbanas en Castilla. El Regimiento: una crisis del siglo XIV en el siglo XV", Edad Media, 8 (2007), pp. 225-241.

Luis López, Carmelo, Colección documental del Archivo Municipal de Piedrahíta (13721549), Ávila: Institución Gran Duque de Alba, 1987.

- Documentación Medieval Abulense en el Registro General del Sello, vol. II, Ávila: Institución Gran Duque de Alba, 1993.

- Documentación medieval de Piedrahita: estudio, edición crítica e índices, vol. I, Ávila: Institución Gran Duque de Alba, 2007. 
- "Estudio" en Documentación medieval de Piedrahíta: estudio, edición crítica e índices, vol. I, Ávila: Institución Gran Duque de Alba, 2007, pp. 15-77.

- Documentación medieval de Piedrahíta: estudio, edición crítica e índices, vol. III, Ávila: Institución Gran Duque de Alba, 2012.

Luis López, Carmelo, y Ser Quijano, Gregorio del, Documentación Medieval del Asocio de la Extinguida Universidad y Tierra de Ávila, vol. I, Ávila: Institución Gran Duque de Alba, 1990.

López-Guadalupe Pallarés, Miguel José, "Eficacia resolutiva del poder: realengo y señorío en el marco concejil. Los casos de Cuéllar (1464-1492) y Sepúlveda (1472-1504)", en El acceso al trono: concepción y ritualización. XLIII Semana de Estudios Medievales. Estella, Navarra: Gobierno de Navarra, 2017, pp. 353-363.

- "Procesos de señorialización en los concejos de la Extremadura castellano-leonesa. Un estado de la cuestión", Espacio, Tiempo y Forma. Serie III. Medieval 31 (2018), pp. 431 454.

López Pita, Paulina, “Señoríos nobiliarios bajomedievales”, Espacio, Tiempo y Forma. Serie III. Medieval, 4 (1991), pp. 243-284.

Lozano Castellanos, Alicia, "E por muchas obras que de vos he recibido. El linaje García de la Rúa y Talavera de la Reina a mediados del siglo XV. Ejemplo de ascenso social y político por servicio al señor de la villa", Historia. Instituciones. Documentos, 41 (2014), pp. 321-344.

- "Controlando el regimiento. La nobleza de Talavera de la Reina y sus métodos de intervención política en el concejo en la Baja Edad Media”, En la España Medieval, 38 (2015), pp. 37-55.

Luis López, Carmelo, La comunidad de villa y tierra de Piedrahíta en el tránsito de la Edad Media a la Moderna, Ávila: Diputación Provincial, 1987.

Martín Rodríguez, José Luis, Documentación Medieval Abulense en el Registro General del Sello, vol. VII, Ávila: Institución Gran Duque de Alba, 1996.

Martínez Díez, Gonzalo, Las comunidades de villa y tierra de la Extremadura castellana: estudio histórico-geográfico, Madrid: Editora Nacional, 1983.

Mínguez Fernández, José María, "La resistencia antiseñorial del concejo de Cáceres durante el siglo XV", Norba. Revista de Arte, Geografia e Historia, 1 (1980), pp. 219-230.

Monsalvo Antón, José María, "El reclutamiento del personal político concejil. La designación de corregidores, alcaldes y alguaciles en un concejo del siglo XV", Studia Historica. Medieval, 5 (1987), pp. 173-195.

- El sistema político concejil. El ejemplo del señorío medieval de Alba de Tormes y su concejo de villa y tierra, Salamanca: Ediciones Universidad de Salamanca, 1988.

- "La sociedad política en los concejos castellanos de la meseta durante la época del Regimiento medieval. La distribución social del poder", en Concejos y ciudades en la Edad Media hispánica: II Congreso de estudios medievales, León: Fundación Sánchez Albornoz, 1990, pp. 359-413.

- "Las dos escalas de la señorialización nobiliaria al sur del Duero: concejos de villa y tierra frente a la señorialización 'menor'. (Estudio a partir de casos del sector occidental: señoríos abulenses y salmantinos)", Revista d Historia Medieval, 8 (1997), pp. 275-338.

- "Centralización monárquica castellana y territorios concejiles (algunas hipótesis a partir de las ciudades medievales de la región castellano-leonesa), Anales de la Universidad de Alicante. Historia Medieval, 13 (2000-2002), pp. 157-202.

- "Torres, tierras, linajes: mentalidad social de los caballeros urbanos y de la elite dirigente en la Salamanca medieval (siglos XIII-XV)", en José M. Monsalvo Antón (coord.), 
Sociedades urbanas y culturas políticas en la baja Edad Media castellana, Salamanca: Universidad de Salamanca, 2013, pp. 165-230.

- "Arraigo territorial de las grandes casas señoriales (Infantes de Aragón, Alba, Estúñiga y Albuquerque) en la cuenca suroccidental del Duero en el contexto de la pugna 'noblezamonarquía '”, Anales de la Universidad de Alicante. Historia Medieval, 19 (2015-2016), pp. 99-152.

- "Relaciones entre nobleza y monarquía en el siglo XV: faccionalismo y acción política de los Álvarez de Toledo (Casa de Alba), Studia Historica. Medieval, 34 (2016), pp. 149185.

Moreno Núñez, José Ignacio, “Los Dávila, linaje de caballeros abulenses”, En la España Medieval, 3 (1982), pp. 157-172.

- "El regimiento de Toro en el siglo XV", En la España Medieval, 6 (1985), pp. 773-796.

- Ávila y su tierra en la baja Edad Media (siglos XIII-XV), Valladolid: Junta de Castilla y León, 1992.

- "Los señoríos de Navamorcuende, Cardiel y Villatoro, bienes vinculados. La quiebra del orden sucesorio y el mayorazgo de 1449", Documenta \& Instrumenta, 5 (2007), pp. 99127.

Moxó, Salvador de, “Los señoríos. En torno a una problemática para el estudio del régimen señorial”, Hispania, 95 (1964), pp. 399-430.

Muñoz Gómez, Víctor, “Administración señorial y gobierno urbano durante los primeros Trastámara. Los corregidores del infante Fernando de Antequera y Leonor de Albuquerque (1392-1421)", en Actas IV Simposio Internacional de Jóvenes Medievalistas, Murcia: Universidad de Murcia, 2008, pp. 161-185.

- "El concejo de Peñafiel. Gobierno y sociedad en una villa vallisoletana en la Edad Media", Miscelánea Medieval Murciana, 34 (2010), pp. 71-81.

Ordenanzas Reales de Castilla (Ordenamiento de Montalvo), Alcalá de Henares: Sebastián Martínez, 1565.

Reglero de la Fuente, Carlos Manuel, "Imágenes, espacios, gestos y palabras en un conflicto: el señorío de Sahagún (siglos XIII-XV)”, Studia Histórica. Medieval, 36/1 (2018), pp. 85-106.

Ruiz de la Peña, Juan Ignacio, "El régimen municipal de Plasencia en la Edad Media: del concejo organizativo y autónomo al Regimiento", Historia. Instituciones. Documentos, 17 (1990), pp. 247-266.

Sánchez Benito, José María, "El poder en una pequeña ciudad castellana: el ejemplo de Huete en el siglo XV", En la España Medieval, 25 (2002), pp. 177-212

- "Algunas consideraciones sobre nobleza territorial, concejos y ciudades a través de un ejemplo: Cuenca y Huete entre fines del siglo XIII y comienzos del XV", Studia Historica. Medieval, 34 (2016), pp. 187-211.

Santos Canalejo, Elisa de, "Piedrahíta, su comunidad de villa y tierra y los duques de Alba en el siglo XV”, En la España Medieval, 5 (1986), pp. 1141-1174.

Ser Quijano, Gregorio del, Documentación medieval de Piedrahíta: estudio, edición crítica e índices, II (1448-1460), Ávila: Institución Gran Duque de Alba, 2010.

- Las finanzas de un concejo castellano: Piedrahíta, siglos XV-XVI, vol. II, Ávila: Institución Gran Duque de Alba, 2011.

- "Fiscalidad real y señorial en el señorío de Valdecorneja a mediados del siglo XV", en Pablo de la Cruz Díaz, Fernando Luis Corral, e Iñaki Martín Viso (coords.), El historiador y la sociedad: homenaje al Prof. José M. Mínguez, Salamanca: Ediciones Universidad de Salamanca, 2013, pp. 253-266. 
Tena García, María Soledad, Las finanzas de un concejo castellano: Piedrahíta, siglos XVXVI, vol. V, Ávila: Institución Gran Duque de Alba, 2011.

Val Valdivieso, María Isabel del, "Oligarquía versus Común (Consecuencias sociopolíticas del triunfo del Regimiento en las ciudades castellanas)”, Medievalismo, 4 (1994), pp. 41-58. 